\section{French nuclear tests at Mururoa}

SIR - In connection with your news report about French nuclear tests at Mururoa Atoll (Nature 377, 91-92; 1995), I should like to clarify the Greenpeace assertion about traces of caesium-134 ("a known product of nuclear fission") indicating leakage of radioactivity around the atoll from past French underground nuclear tests. This is very doubtful. Caesium-134 is not a direct product of nuclear fission, but is created from caesium-133 by the absorption of a neutron. As a consequence, caesium-134 is not significantly produced in a nuclear explosion, but is produced in prodigious quantities in nuclear reactors. (See Table 1.3 of Radioactivity after Chernobyl SCOPE 50, edited by Warner and Harrison, in which radioactive releases from nuclear detonations and nuclear reactor accidents are compared.) Indeed, one of the first tests undertaken of a radioactive plume is to examine it for the presence of caesium134 to establish if the source was a weapon or a reactor. This was done, for example, by the Swedes in 1986 when they were the first in the West to announce the reactor accident at Chernobyl.

In a French study (Bourlat and Martin $J$. env. radioactivity $17,13-29 ; 1992)$ to verify if caesium-134 traces were present in Mururoa lagoon as reported by the Cousteau Foundation in 1987, no trace was found. Measurements of radionuclides in seawater and plankton collected outside Mururoa Atoll were also conducted under the sponsorship of the International Atomic Energy Agency (IAEA) by three independent international laboratories, to provide an intercomparison of results (IAEA/AL/044, (AEA-ILMR Report 48, July 1991). The only man-made radionuclides they detected were strontium-90, caesium-137 and plutonium-238, 239 and 240.

The question remains: where did the caesium-134 detected by the Cousteau Foundation come from? Bourlat and Martin refer to a New Zealand study that found evidence that it could have come from laboratory samples contaminated with Chernobyl radioactivity (Cambray et al. New Zealand Radioactivity Annual Reports 1986-1990).

For the past two years, I have served as the executive director of an international collaborative study of the radioactivity from nuclear tests, called RADTEST. Sponsored by SCOPE (the Scientific Committee on Problems of the Environment, based in Paris), our study has focused on human exposure and the effects from nuclear weapons test fallout. We have found that the principal hazard is from local early fallout from atmospheric ground or near-ground bursts. A lower level impact is from global delayed fallout There is no significant human exposure from underground bursts except when the radioactivity vents from the surface, which has occurred on numerous occasions. Limited studies of migration from contained underground tests in Nevada in the United States and at Semipalatinsk in Russia indicate very slow movement, and hence only a potential human hazard in the very long term. If the proposed French tests are properly contained, there should be minimal human exposure. As to possible environmental damage to the atoll, this is beyond the scope of the RADTEST study.

\section{Charles S. Shapiro}

Regional Atmospheric Sciences Division, Lawrence Livermore National Laboratory, PO Box 808, L-262,

Livermore, California 94551, USA

SIR - Your leading article "France and nuclear illusion” (Nature 377, 89; 1995) smacks of typical Anglo-Saxon solidarity and double standards.

"France has no better case than Britain for maintaining separate nuclear forces", you state. OK. But then what is the case for Russia or for the United States? For the latter because they (and only they in history) have already used it?

"Accidents of postcolonialism should have given France the right...". What do you think Australians and New Zealanders are? Natives? Of course, in these countries there are few natives left who could protest about anything!

\section{J. E. Dumont}

Université Libre de Bruxelles,

Campus Hôpital Erasme,

Route de Lennik 808 ,

1070 Brussels, Belgium

\section{Historic apoptosis}

SIR - In his interesting film review, Peter Tallack" asks "Why... has something so fundamental as apoptosis been ignored for so long?" The popular view, reiterated in countless papers, is that apoptosis was missed until unexpectedly brought to light in 1949 or 1972 or still more recently.

The truth is that naturally occurring cell death (including the concept of apoptosis, though not the name) was a flourishing subject at the end of the nineteenth century, and was systematically reviewed by Barfurth each year between 1893 and 1913 in the Ergebnisse der Anatomie und Entwicklungsgeschichte under the heading "Involution", but then went out of fashion.

The first report that cells die naturally in development was Carl Vogt's account ${ }^{2}$ of dying notochordal and cartilaginous cells in 1842, which was remarkably soon from atmospheric ground and air-bursts. after the establishment of the cell theory by Schleiden and Schwann between 1839 and 1842. The next landmark was August Weismann's detailed description ${ }^{3}$ in 1864 of massive cell death in pupating diptera, which triggered others into writing a dozen papers on this subject between 1870 and 1890, although Weismann himself gave it up because of an eye disease and achieved immortality theorizing about the immortal germ plasm.

Other landmarks were Stieda's description in 1872 of chondrocyte death during endochondral ossification, Metschnikoff's account in 1883 of phagocytosis associated with cell death in the muscles of metamorphic toads, and Beard's discovery in 1889 that an entire population of neurons is lost in fish embryos. The first report of scattered cell death in a tissue destined to remain was that of Felix ${ }^{4}$ in 1889 on developing mammalian muscle. Neuronal death among developing motoneurons and spinal ganglion cells was described in 1906 by Collin ${ }^{5}$, who understood the numerical importance of the phenomenon, and argued that an overproduction of cells followed by degeneration of the excess may be common to all tissues.

The occurrence of different kinds of degeneration was common knowledge to pathologists by the $1860 \mathrm{~s}$, but the first clear morphological description of apoptosis was that of Flemming ${ }^{6}$ in 1885 in a study of naturally regressing ovarian follicles. He called it "chromatolysis", and the term was widely used for this kind of cell death during the next 30 years. As has recently been pointed out ${ }^{7}$, the occurrence of this type of cell death in breast cancer was reported in 1892, and the need of it to counterbalance mitosis was argued by Gräper in 1914.

Most of the nineteenth-century reports were written in German, and the reduced interest in cell death after about 1914 seems to have been due partly to the increasing proportion of scientists unable to read that language. The torch was, however, kept alight by embryologists such as M. Ernst, H. Fell and A. Glücksmann in the period between the two wars, followed by V. Hamburger and R. LeviMontalcini over the subsequent two decades. The rest is common knowledge.

Peter G. H. Clarke

Institute of Anatomy,

Stephanie Clarke

Institute of Physiology,

University of Lausanne,

1005 Lausanne,

Switzerland

1. Tallack, P. Nature 377, 393 (1995)

2. Vogt, C. Untersuchungen (ber die Entwicklungsgeschichte der Geburtshelferkroete (Alytes obstetricans) (Jent und Gassmann, Solothurn, 1842).

3. Weismann, A. Z. f. wissenschaft. Zool. 14, 187-336 (1864).

Felix, W. Z f wissenschaft. Zool. 48, 224-259 (1889)

4. Felix, W. Z. f. wissenschaft. Zool. 48,
5. Collin, R. Névraxe 8, 181-309 (1906).

6. Flemming, W. Arch. f. Anat. und Physiol. Jahrgang 1885 221-244 (1885)

Majno, G. \& Joris, I. Am. J. Path. 146, 3-15 (1995). 